\title{
ON THE EXPERIMENTAL STUDY OF COMPOSITE DESSICANTS FOR ENERGY EFFICIENT AIR DEHUMIDIFICATION
}

\author{
K.J. CHUA AND M.R. ISLAM \\ Department of Mechanical Engineering, Engineering Science Programme, \\ National University of Singapore, 9 Engineering Drive 1, Singapore 117576. \\ mpeckje@nus.edu.sg, and espmri@nus.edu.sg
}

(Received: August 3, 2015; Accepted: October 30, 2015; Published on-line: November 30, 2015)

ABSTRACT: This paper presents the development and performance characterization of new composite desiccants. The main compositions for the composite desiccants include silica gel, lithium chloride, calcium chloride and bentonite. Different percentage compositions of these four components were tested to determine the optimal material composition for improving moisture removal capacity under varying inlet air temperature and humidity, and amount of moisture released under different regenerative temperature. For the first time, four-layered composite desiccants were developed and tested experimentally to determine their moisture removal capacity and moisture regeneration capacity at temperature of about $60^{\circ} \mathrm{C}$ under inlet air conditions similar to Singapore's tropical climate. The performances of these composite desiccants were benchmarked with the performance of pure silica gel - the most commonly used desiccant in the market today. It was observed experimentally, that employing a fourlayered composite desiccant, comprising silica-gel $\left(\mathrm{SiO}_{2}\right)$, Bentonite, Lithium Chloride $(\mathrm{LiCl})$, and Calcium Chloride $\left(\mathrm{CaCl}_{2}\right)$, has enabled greater moisture removal capacity for varying inlet air temperature and humidity ranging from 25 to $35^{\circ} \mathrm{C}$ and 55 to $95 \%$ relative humidity $(\mathrm{RH})$. The percentage improvements, in contrast to pure silica gel, are 14 to $22.5 \%$, and 10 to $26.3 \%$ for varying inlet air temperature and varying inlet $\mathrm{RH}$, respectively.

ABSTRAK: Kertas kerja ini membentangkan perkembangan dan prestasi pencirian desiccants komposit baru. Komposisi utama bagi desiccants komposit termasuk gel silika, litium klorida, kalsium klorida dan bentonit. Peratusan komposisi yang berbeza daripada empat komponen telah diuji untuk menentukan komposisi bahan yang optimum untuk meningkatkan penyingkiran kapasiti kelembapan di bawah pelbagai suhu masuk udara dan kelembapan, dan jumlah kelembapan dikeluarkan di bawah suhu regeneratif yang berbeza. Buat kali pertama, desiccants komposit empat lapis telah dibangunkan dan diuji secara eksperimen untuk menentukan penyingkiran kelembapan kapasiti dan kelembapan kapasiti penjanaan semula mereka pada suhu kira-kira $60^{\circ} \mathrm{C}$ di bawah keadaan udara masuk sama dengan iklim tropika di Singapura. Persembahan ini desiccants komposit ditanda aras dengan prestasi gel silika tulen - bahan pengering yang paling biasa digunakan dalam pasaran hari ini. Diperhatikan, uji kaji, yang menggunakan bahan pengering komposit empat lapisan yang terdiri daripada silika gel $\left(\mathrm{SiO}_{2}\right)$, Bentonit, Lithium Chloride ( $\mathrm{LiCl})$, dan Kalsium Klorida $\left(\mathrm{CaCl}_{2}\right)$, telah membolehkan lebih besar penyingkiran kapasiti kelembapan bagi mengubah suhu udara masuk dan kelembapan antara 25 hingga $35^{\circ} \mathrm{C}$ dan 55 hingga $95 \%$ kelembapan relatif (RH). Peningkatan peratusan, berbeza dengan gel silika tulen, 14 ke $22.5 \%$, dan 10 hingga $26.3 \%$ bagi mengubah masuk suhu udara dan berbeza-beza masuk RH, masing-masing.

KEYWORDS: experiments; composite desiccant; dehumidification; energy efficiency 


\section{INTRODUCTION}

There is a need to control the temperature and relative humidity $(\mathrm{RH})$ in the indoor environment of buildings to achieve a specified range of human thermal comfort. Air that is too dry will cause human discomfort ranging from dry skin to respiratory irritation. According to American Society of Heating, Refrigeration and Air Conditioning Engineers (ASHRAE), air with relative humidity of less than $30 \%$ will cause such discomfort [1]. It is also of great importance to control the temperature and relative humidity in certain industries such as the food, medical, and electronic industries. The controlled humidity condition helps to slow down the growth of bacteria and reduces the spread of viral infections through air [2]. In Singapore, the use of air-conditioning has become a norm in practically every building. In fact, about $50 \%$ of a building's energy consumption is attributed to air-conditioning alone [3]. With the rising price in electricity and the depletion of fossil fuels, it is therefore, necessary to increase the efficiency of airconditioners to reduce the energy consumption for the consumers.

Many research works have been conducted on the different types of desiccant available for the dehumidification process. These desiccants could be broadly categorised into liquid and solid states. Each has its own strengths and shortcomings. Liquid desiccants are widely deployed in their utilization due to their ability to incur lower pressure drop and to regenerate at lower temperature [4,5]. However, liquid desiccants are also known to be toxic and corrosive in nature which renders them to be unsuitable for airconditioning applications. Also, liquid desiccants are also found to have carryover effects [4]. Some examples of liquid desiccants are lithium chloride, lithium bromide and calcium chloride.

Solid desiccants are more compact and most importantly, there is less tendency for them to corrode and provide carryover effects [6]. Solid desiccants are, in general, dependent on its porous form, surface area, surface energy and crystalline structure to adsorb moisture from the air [7,8]. Examples of solid desiccants include silica gels, zeolites, activated carbon and activated clay such as bentonite. The most commonly used desiccants in the market today for air-conditioning application is silica gel due to their great pro surface area and good moisture adsorption capacity [9].

Since solid desiccants and liquid desiccants have their advantages and disadvantages, it is suggested that combining both by mixing them chemically or physically will help to overcome the individual shortcomings of each type. For instance, combination of silica gels with lithium chloride will help to reduce the effect of toxicity and to reduce the regeneration temperature achieving the intermediate characteristic [10]. Many research works have been carried out in this field where these desiccants are referred to as composite desiccants. Commonly used solid desiccants such as silica gel, activated carbon and molecular sieves such as zeolites were conducted in several experiments $[8,11,12]$. Silica gel has high moisture adsorption capacity and low regenerative temperature of $120^{\circ} \mathrm{C}$. It is also established that adsorption capacity of silica gel generally decreases with the rise in temperature [8]. Activated carbon and alumina required a higher regeneration temperature of $250^{\circ} \mathrm{C}$ for a less adsorption capacity as compared to silica gel. Molecular sieves such as zeolites are found to have the largest amount in moisture adsorption capacity due to its large pore size and highly polar surface [13]. However, the deterring factor for using it as desiccant is the high regenerative temperature of $350^{\circ} \mathrm{C}$ that it requires.

Composite desiccants made by impregnating hygroscopic substance in the pores of solid adsorbents have been found to be effective in increasing the moisture adsorption 
capacity of the adsorbents and they are called selective water sorbents [14]. One example is the combination of activated carbon with inorganic salts such as lithium chloride and calcium chloride [15]. For the same amount of lithium chloride content and calcium chloride content added to the activated carbon, the former has a better moisture adsorption performance [15]. At the same condition of $84 \%$ relative humidity, activated carbon impregnated with lithium chloride can adsorb moisture as much as $194 \%$ of its mass as compared to the one with calcium chloride where its moisture adsorption is $170 \%$ of its mass.

Many experiments have also been conducted for composite desiccants consisting of calcium chloride being contained in the pores of silica gel [16-18]. The moisture adsorption capacity of this composite desiccant is better than that of silica gel. It is also established that the deciding factor in the improvement of the sorption capacity is the percentage of calcium chloride content in the mixture.

Combinations of silica gel and lithium chloride have also been experimented $[10,19,20]$. Similar to calcium chloride, the lithium chloride content in the composite desiccants plays a huge role in the moisture adsorption capacity. It is also a well-known that lithium chloride is corrosive in nature and this halts the progress of lithium chloride as a liquid desiccant. However, by impregnating it in silica gel, its corrosive effect is kept to the minimum and the combined desiccant also benefits in terms of moisture regeneration.

Another type of composite desiccant that is of great commercial interest is the lowcost composite desiccant. Since clay is cheap in price and can adsorb moisture moderately, by combining it with the hygroscopic substance, its moisture removal capacity will also be improved. Research has also been done and it is found to have reasonable performances $[21,22]$. For small-scale application, where moisture removal is not prominent, this desiccant is good enough for application. However, it is observed that after going through cycles of sorption and desorption process, cracks are created on the surface of the desiccant while the overall structure remains intact. Its regeneration temperature is found to be less than $100^{\circ} \mathrm{C}$ and low-grade waste heat can be utilized to regenerate it.

It is clear from the mentioned literature that the primary focus is on the dehumidification and regeneration capacity of either basic adsorbents such as silica gel and zeolites and basic adsorbents-halides. To date, very limited research work has been done on comparing different composite desiccants under the same operating condition. In this article, the combination of four layered composite desiccants will be explored to determine the highest moisture removal capacity at varying temperatures and $\mathrm{RH}$ and also the highest regenerative moisture capacity under different temperature environments. The four types of desiccating materials are silica gel, bentonite, lithium chloride and calcium chloride.

\section{MATERIALS AND METHODS}

\subsection{Experimental Setup}

A laboratory small-scale experimental setup, shown in Fig. 1, was used to test the performance of the composite desiccants. The setup, comprised of a polypropylene air tunnel with low thermal conductivity, was used to host different composite desiccants and to let the process air pass through the desiccant. The process air was drawn in by using a suction pump. Thermo/Hygrometer sensors and velocity sensor were mounted on the setup as shown in the schematic diagram in Fig. 1 to measure the condition of the air before and after passing through the desiccant. 
The process air to be directed to the desiccant was first conditioned in the metal box condition chamber (depicted in Fig. 2b) while allowing the air to flow through the bypass section. With the help of a system controller and a humidifier, the temperature and RH of the incoming air were judiciously controlled. After achieving the target air temperature and relative humidity, the valves were switched to let the process air to flow through the desiccant in place. The air flow continued until the tested composite desiccant reached its saturation state.

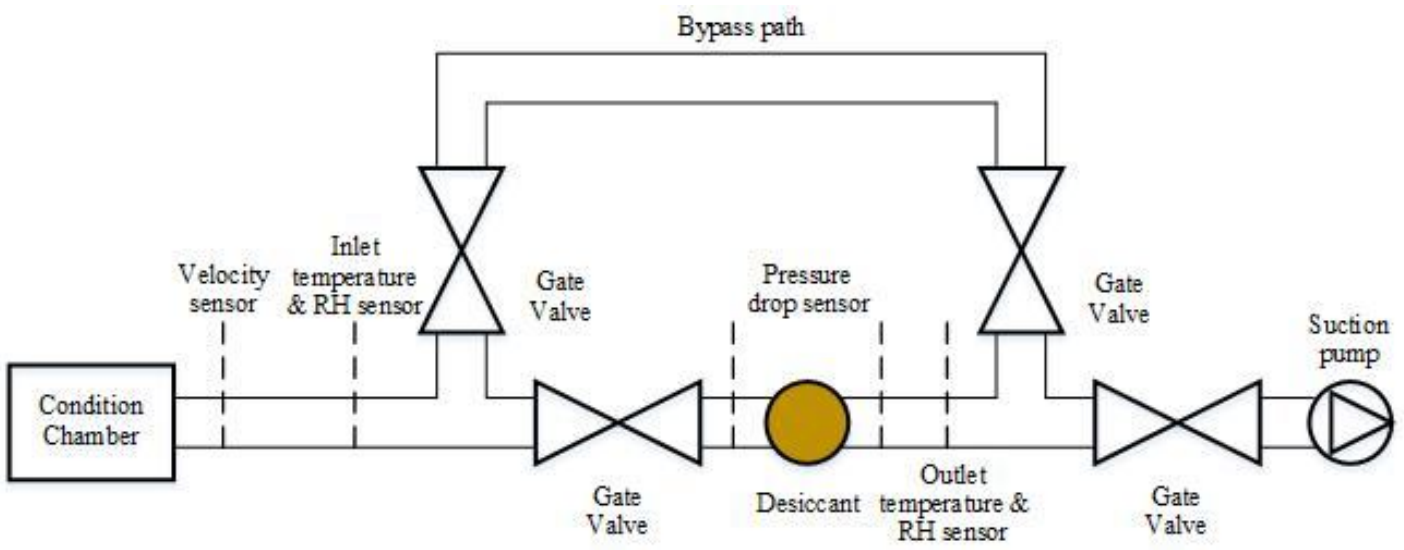

Fig. 1: Schematic Diagram of small-scale system.
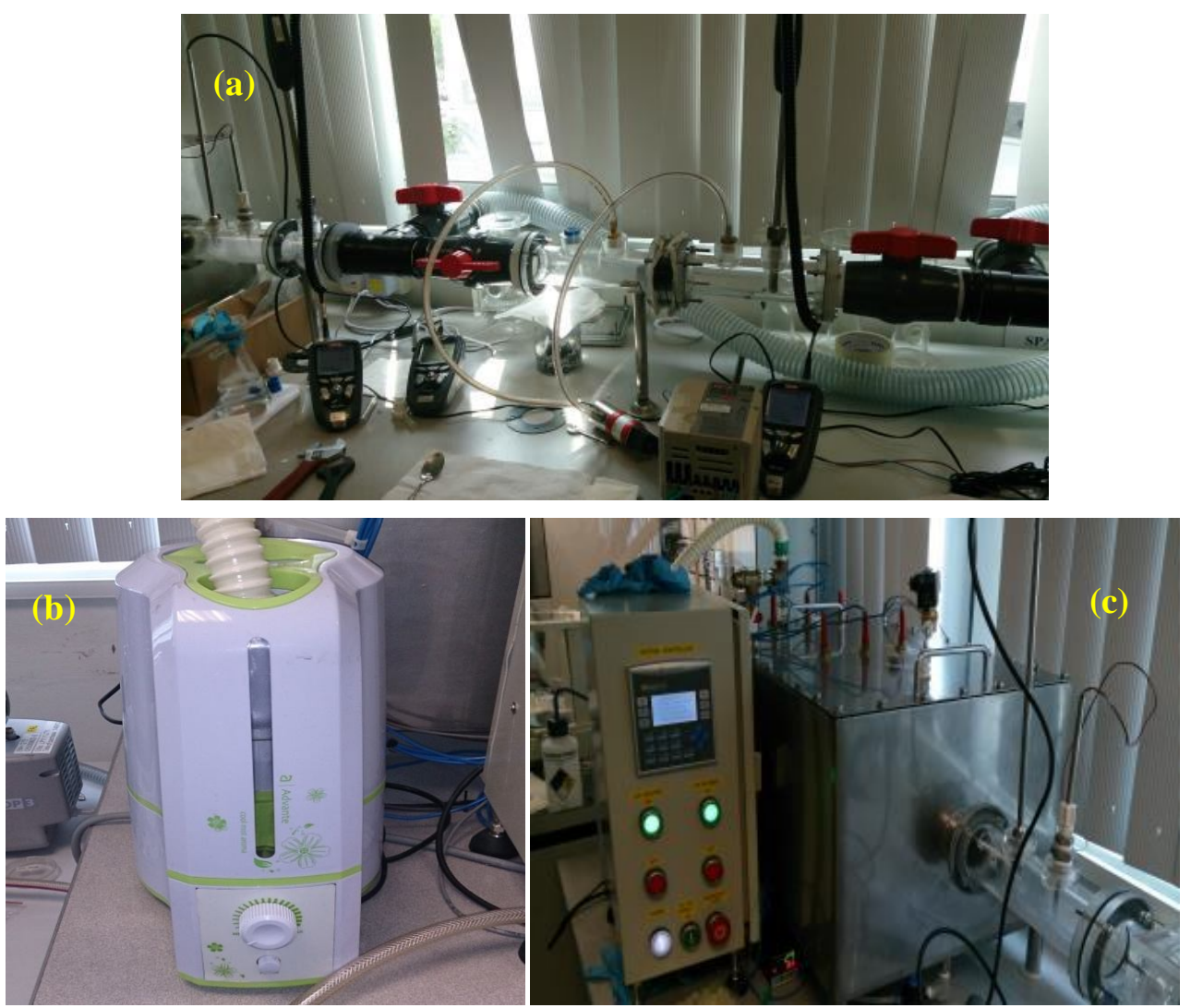

Fig. 2: (a) A pictorial view of the actual small-scale system setup; (b) a condition chamber with system controller; (c) a humidifier to regulate the humidity of the inlet air to the experimental setup. 
To switch the process to the regeneration mode (moisture desorption), there was a need to condition the air again in the metal box which increases the air temperature to the required regenerative level. The flow of air was again directed through the bypass section. After the target temperature was achieved, the air was passed through the desiccant to allow it to release the moisture it adsorbed.

Sigma-Aldrich supplied the desiccants used in the experiments. In the set-up, the temperature and relative humidity of the process and outlet air are measured by using a series of accurate and digital thermo/hygrometers. The sensor model used to measure temperature and humidity is Kimo TH200. The upper limit of the measurable temperature is $120^{\circ} \mathrm{C}$, the lower limit is $-20^{\circ} \mathrm{C}$ and the precision of the temperature sensor is within $\pm 3 \%$. The relative humidity monitored with the sensor ranges from $0 \%$ to $100 \% \mathrm{RH}$ and its precision is within $\pm 5 \%$. The measuring points are located far from the air fan so as to minimize interference to the measurements. A Kimo CTV100 air velocity transmitter is employed to measure the air flow rate, and its precision is 3\%. A Konics Series SS-3010 measures the pressure difference of the wheel with an accuracy of $\pm 3 \mathrm{~Pa}$. For regeneration experiments, samples are weighed using a digital weighing scale (Ohaus Explorer, Model E1D120). A dry-heat oven (Memmert GmbH+Co.KG, Model 200) is employed to obtain the bone-dry weights of saturated desiccants over seven hours at $80^{\circ} \mathrm{C}, 100^{\circ} \mathrm{C}$ and $120^{\circ} \mathrm{C}$. The desiccants were regularly taken out at 30 minutes interval and their weights are determined.

The inlet process air used for the experiments was selected to match Singapore's outdoor climate that varies from $25^{\circ} \mathrm{C}$ to $31.2^{\circ} \mathrm{C}$ in temperature and relative humidity of $60 \%$ to as high as $95 \%$ [42]. Efforts to minimize leakage were considered by using rubber or silicone sealants and flanges on areas where leak was likely to occur such as the joints for both the small-scale and large-scale system. Table 1 below shows the geometric parameters of the experimental setup. Table 2 shows the operating air conditions employed for the present dehumidification study.

Table 1: Geometrical parameters of the laboratory experimental setup.

\begin{tabular}{lc}
\hline Geometric Parameters & Values \\
\hline Thickness of desiccant placed in holder, $l_{\text {small }}(\mathrm{m})$ & 0.035 \\
Radius of desiccant holder, $r_{\text {small }}(\mathrm{m})$ & 0.025 \\
Volume of desiccant holder, $V\left(\mathrm{~m}^{3}\right)$ & $6.87 * 10^{-5}$ \\
\hline
\end{tabular}

Table 2: Operating air flow parameters for experiments.

\begin{tabular}{lcc}
\hline Operating Parameters & $\begin{array}{c}\text { Baseline } \\
\text { Value }\end{array}$ & $\begin{array}{c}\text { Parametric } \\
\text { variations }\end{array}$ \\
\hline Temperature of process air, $T_{\text {air }}\left({ }^{\circ} \mathrm{C}\right)$ & 25 & $25-30$ \\
Relative Humidity of process air, $R H(\%)$ & 50 & $50-95$ \\
Process air velocity, $v(\mathrm{~m} / \mathrm{s})$ & 1 & 1 \\
\hline
\end{tabular}

\section{RESULTS AND DISCUSSION}

The performances of the composite desiccants were tested under conditions similar to Singapore's climatic condition that is high in temperature and relative humidity. Research on composite desiccants generally involve two-layered materials that consist of a host matrix with open pores such as silica gel, and a hygroscopic substance such as lithium 
chloride. However in this study, a four-layered composite desiccant was explored and tested. Similar to other studies on composite desiccants, moisture adsorption capacity and regeneration capacity were calculated to compare the performances of the various composite desiccants. In addition to this, pressure drop across the desiccants were also measured and compared as one of the performance indicator of the composite desiccants.

The factors of choosing the most promising composite desiccants are in the following order of importance: moisture adsorption capacity, regeneration capacity at relatively low temperature $\left(600^{\circ} \mathrm{C}\right)$, and pressure losses across the desiccants. Only the better performing desiccants were used for further testing and are discussed in this report. The performance of composite desiccants will be referenced with the performance of the silica gel, since this is the most widely used commercial desiccant for dehumidifying operations.

\subsection{Performance of Composite Desiccants}

Table 3 presents the overview of the performances of the different composite desiccants when they were exposed to air with temperature of $30^{\circ} \mathrm{C}$ and relative humidity of $80 \%$ which is the average climatic condition in Singapore. Based on this table, better performing composite desiccants were judiciously selected to undergo further tests under varying temperature and relative humidity conditions.

Table 3: Adsorption Capabilities and Pressure Difference of the Desiccants at temperature of $300 \mathrm{C}$ and $\mathrm{RH}$ of $80 \%$.

\begin{tabular}{|c|c|c|c|c|c|c|c|c|c|}
\hline \multicolumn{5}{|c|}{ \% Composition by Mass } & \multirow{2}{*}{$\begin{array}{l}\text { Saturation } \\
\text { time (min) }\end{array}$} & \multirow{2}{*}{$\begin{array}{c}\% \text { capacity } \\
\text { of mass of } \\
\mathrm{H}_{2} \mathrm{O} \\
\text { adsorbed }\end{array}$} & \multirow{2}{*}{$\begin{array}{c}\text { Drop } \\
\text { in RH } \\
\text { from } \\
\mathbf{8 0 \%}\end{array}$} & \multirow{2}{*}{$\begin{array}{c}\text { Moisture } \\
\text { removal } \\
\text { capacity } \\
\text { (g/kg of } \\
\text { dry air) } \\
\end{array}$} & \multirow{2}{*}{$\begin{array}{c}\text { Average } \\
\text { Pressure } \\
\text { Difference } \\
\text { (Pa) }\end{array}$} \\
\hline $\mathrm{SiO}_{2}$ & LiCl & $\mathrm{CaCl}_{2}$ & Bentonite & $\begin{array}{l}\text { Activated } \\
\text { Carbon }\end{array}$ & & & & & \\
\hline $100 \%$ & $0 \%$ & $0 \%$ & $0 \%$ & $0 \%$ & 18.5 & $28.50 \%$ & $42.67 \%$ & 8.168 & 353.60 \\
\hline $95.1 \%$ & $4.9 \%$ & $0 \%$ & $0 \%$ & $0 \%$ & 11.6 & $29.70 \%$ & $49.37 \%$ & 8.583 & 384.70 \\
\hline $91.1 \%$ & $8.9 \%$ & $0 \%$ & $0 \%$ & $0 \%$ & 15.0 & $33.40 \%$ & $51.45 \%$ & 9.808 & 389.67 \\
\hline $93.8 \%$ & $0 \%$ & $6.2 \%$ & $0 \%$ & $0 \%$ & 16.5 & $29.40 \%$ & $50.40 \%$ & 7.824 & 348.17 \\
\hline $91.3 \%$ & $0 \%$ & $8.7 \%$ & $0 \%$ & $0 \%$ & 17.7 & $30.51 \%$ & $50.78 \%$ & 8.840 & 368.20 \\
\hline $92.75 \%$ & $3.625 \%$ & $3.625 \%$ & $0 \%$ & $0 \%$ & 17.0 & $30.34 \%$ & $50.24 \%$ & 9.125 & 381.52 \\
\hline $66.92 \%$ & $6.72 \%$ & $6.72 \%$ & $19.64 \%$ & $0 \%$ & 23 & $32.49 \%$ & $41.56 \%$ & 7.780 & 258.29 \\
\hline $64.85 \%$ & $6.85 \%$ & $6.85 \%$ & $21.53 \%$ & $0 \%$ & 23.5 & $32.50 \%$ & $50.67 \%$ & 8.709 & 257.00 \\
\hline $60.44 \%$ & $6.33 \%$ & $6.33 \%$ & $26.90 \%$ & $0 \%$ & 26.0 & $30.50 \%$ & $39.21 \%$ & 7.491 & 245.00 \\
\hline $58.22 \%$ & $5.77 \%$ & $5.77 \%$ & $30.24 \%$ & $0 \%$ & 20.0 & $27.71 \%$ & $35.67 \%$ & 6.759 & 195.00 \\
\hline $0 \%$ & $23 \%$ & $0 \%$ & $0 \%$ & $77 \%$ & 27.5 & $67.29 \%$ & $41.84 \%$ & 8.076 & 124.67 \\
\hline $0 \%$ & $0 \%$ & $23 \%$ & $0 \%$ & $77 \%$ & 25.0 & $44.38 \%$ & $29.57 \%$ & 6.170 & 121.17 \\
\hline
\end{tabular}

Based on the experimental results, the maximum composition of a hygroscopic substance that can be impregnated into the pores of silica gel is approximately $10 \%$ of its mass. From Table 3, regarding moisture removal capacity, the desiccant made from $\mathrm{SiO}_{2}$ $91.1 \%+\mathrm{LiCl} 8.9 \%$ is the best choice. However, it is noted that this desiccant incurred the highest pressure difference across the composite desiccant that translates to greater energy required to draw the air through the desiccant.

It is also observed that composite desiccants involving bentonite reach saturation point at a longer period. In addition, the presence of more bentonite in the mixture generally lowers the pressure drop across the desiccants. This implies that less energy is required to draw the air across the desiccants. The addition of bentonite further promotes 
hygroscopic characteristic in the composite desiccants. Therefore, looking at the requirement for desiccant drying as a whole, the desiccant mixture comprising $\mathrm{SiO}_{2}$ $64.85 \%+\mathrm{LiCl} 6.85 \%+\mathrm{CaCl}_{2} 6.85 \%+$ bentonite $21.53 \%$ seems to be the better choice at temperature of $300^{\circ} \mathrm{C}$ and relative humidity of $80 \%$. It has a relatively high moisture removal capacity and an average pressure difference that is relatively low (27\% lower than silica gel) primary due to presence of bentonite that binds the mixture together. Its performance under the varying temperature and relative humidity, and its regenerative capability is presented in the ensuing sections.

It can also be noted from Table 3 above that composite desiccants involving activated carbon have very high moisture removal capacity by mass. Essentially, these can hold more hydrophilic salt on the surface. Base on the experiments, the maximum composition of hydrophilic salt that activated carbon can contain is about $23 \%$ of its mass as compared to silica gel that contains $9 \%$ of its mass. The low pressure drop across the activated carbon composite desiccant is also very attractive. However, regarding the absolute amount of moisture that is removed by activated-carbon embedded composite desiccants, the quantity is rather low. Since the packing density of activated carbon composite desiccant in the holder is rather small. Therefore, despite the high moisture removal capacity by mass, the physical mass of water vapour that it adsorbed is lower than other composite desiccants.

\subsubsection{Moisture Removal Capacity against Temperature}

In Fig. 3(a), it is observed that the addition of $\mathrm{LiCl} / \mathrm{CaCl}_{2}$ helps to increase the moisture removal capacity when the inlet air temperature is varied. The effect of $\mathrm{LiCl}$ increases the moisture removal capacity of the composite desiccants by about $20 \%$ compared to $\mathrm{CaCl}_{2}$ which increases the moisture removal capacity by about $10 \%$.

It is apparent in Fig. 3(b) that the addition of bentonite to the composite desiccants reduces their moisture removal capacity. The graphs indicate that even with the presence of both $\mathrm{LiCl}$ and $\mathrm{CaCl}_{2}$, the moisture removing performance of the composite desiccants compared to pure silica gel does not differ much. It is observed that the best performing desiccants is $\mathrm{SiO}_{2} 64.85 \%+$ bentonite $21.53 \%+\mathrm{LiCl} 6.81 \%+\mathrm{CaCl}_{2} 6.81 \%$. When compared to silica gel, the moisture removal capacity improved by about $10 \%$. Also, from Fig. 3(c), it is apparent that under humid outdoor air conditions, the best moisture removal capacity is $\mathrm{SiO}_{2} 91 \%+\mathrm{LiCl} 9 \%$ followed by $\mathrm{SiO}_{2} 64.85 \%+$ bentonite $21.53 \%+\mathrm{LiCl}$ $6.81 \%+\mathrm{CaCl}_{2} 6.81 \%$. The improvement in moisture removal capacity spans $14 \%$ to $22.5 \%$ when benchmarked with silica gel. In summary, the graphs displayed in Fig. 3(a) to (c) show that the moisture removal capacity of different composite desiccants with varying temperature keeping the RH constant at $80 \%$. In general, the moisture removal capacity of composite desiccants increases with temperature at constant RH.

\subsubsection{Moisture Removal Capacity against Relative Humidity}

In Fig. 4(a), it is observed that the addition of Lia helps to promote the moisture removal capacity of the composite desiccants by about $20 \%$ at $\mathrm{RH}$ greater than $70 \%$. The addition of $\mathrm{CaCl}_{2}$ does not appear to have a major impact on the performance of the desiccant under varying $\mathrm{RH}$ conditions. In fact, at $\mathrm{RH}$ lower than $70 \%$, the performance of pure silica gel is observed to be better.

From Fig. 4(b), it is observed that the addition of bentonite to the composite desiccants helps to bind the desiccants together but it reduces the moisture removal capacity of the desiccants. As shown from the graph, even with the presence of both $\mathrm{LiC}$ 
and $\mathrm{CaCl}_{2}$, there is not much difference in its performance when compared to pure silica gel for $\mathrm{RH}$ above $70 \%$.

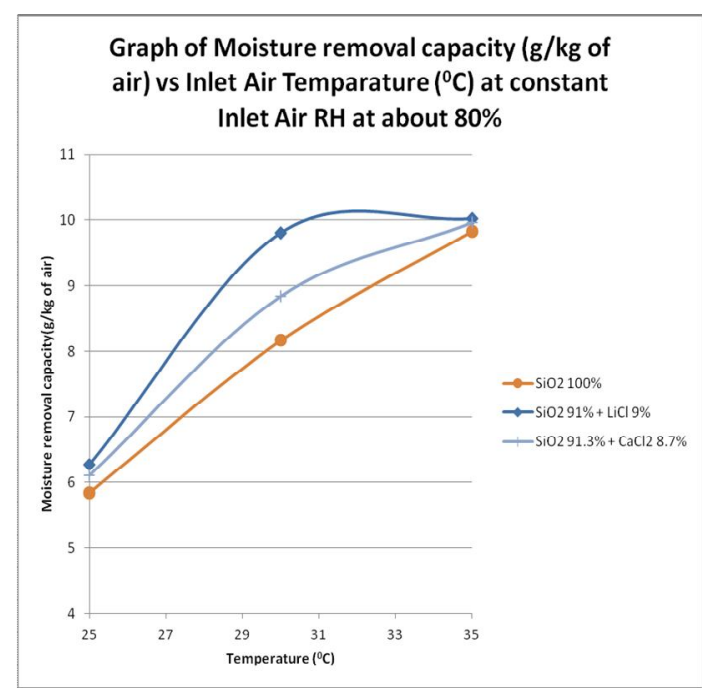

(a)

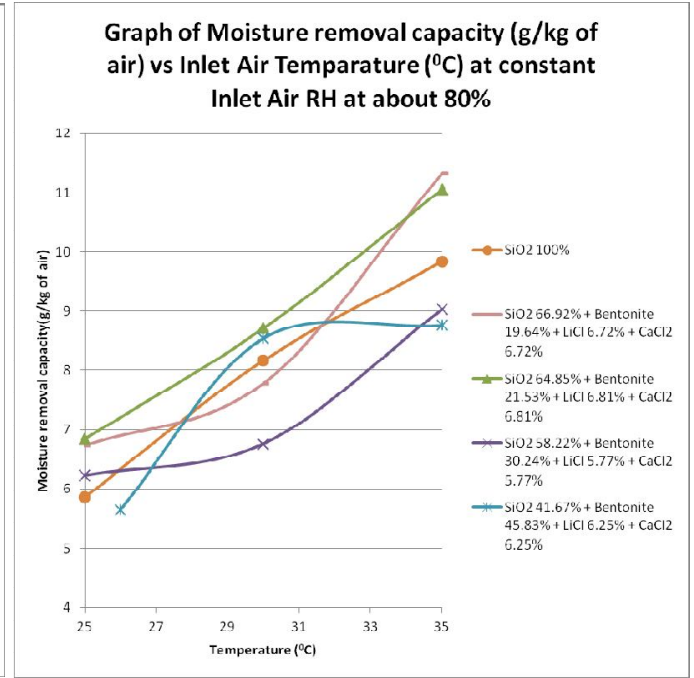

(b)

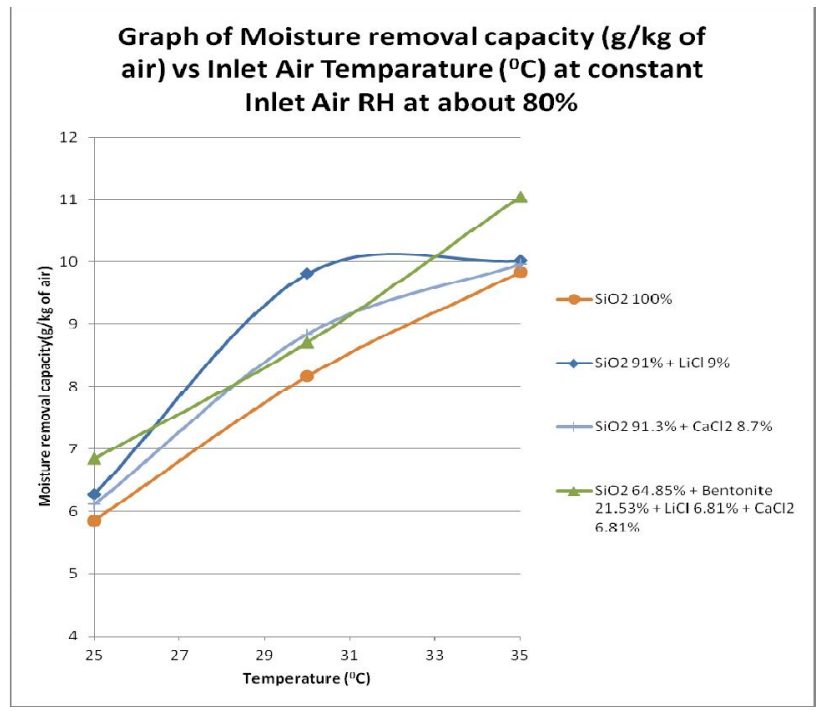

(c)

Fig. 3: (a) Moisture removal capacity of two-layered composite desiccants compared to silica gel at varying temperature; (b) moisture removal capacity of four-layered composite desiccants compared to silica gel at varying temperature; and (c) moisture removal capacity of best composite desiccants as compared to silica gel at varying temperature.

Figure 4(c) shows that the composite desiccants with the best moisture removal capacity for simulated inlet air conditions similar to Singapore's external weather is $\mathrm{SiO}_{2}$ $91 \%+\mathrm{LiCl} 9 \%$ followed by $\mathrm{SiO}_{2} 91.3 \%+\mathrm{CaCl}_{2} 8.7 \%$, and $\mathrm{SiO}_{2} 64.85 \%$ + bentonite $21.53 \%+\mathrm{LiCl} 6.81 \%+\mathrm{CaCl}_{2} 6.81 \%$. Under varying $\mathrm{RH}$ conditions, the improvement in moisture removal capacity spans $10 \%$ to $26.3 \%$ when benchmarked with silica gel. 


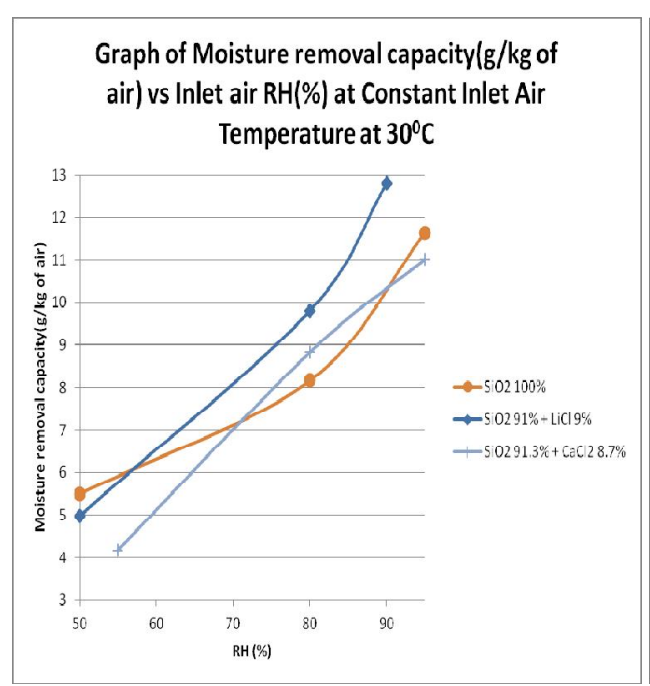

(a)

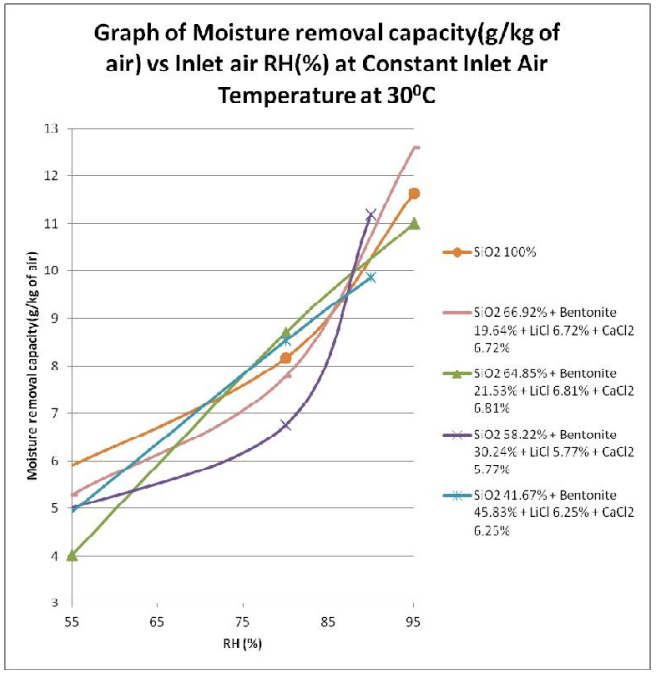

(b)

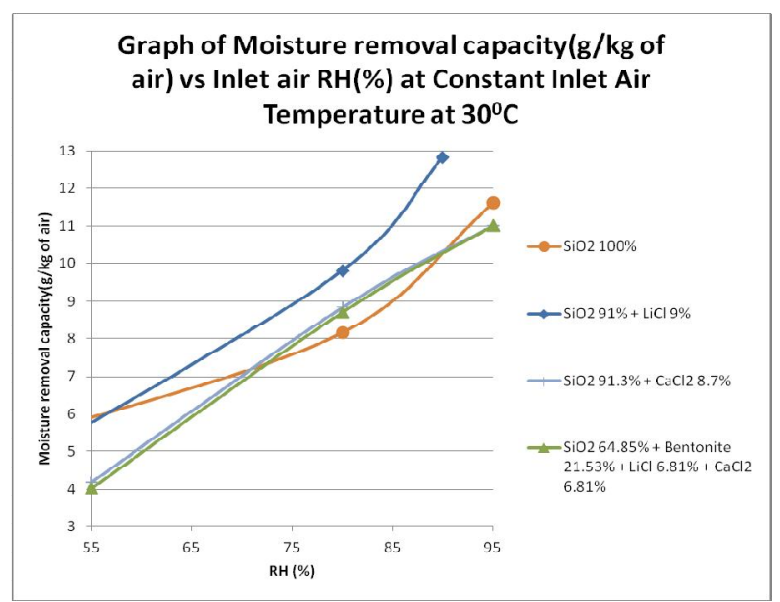

(c)

Fig. 4: (a) Moisture removal capacity of two-layered composite desiccants compared to silica gel at varying RH; (b) moisture removal capacity of four-layered composite desiccants compared to silica gel at varying RH; and (c) moisture removal capacity of best composite desiccants as compared to silica gel at varying RH.

In summary, the graphs portrayed in Fig. 4(a) to (c) show the moisture removal capacity of different composite desiccants at varying $\mathrm{RH}$ from $55 \%$ to $90 \%$ at constant temperature at $30^{\circ} \mathrm{C}$. For all the composite desiccants studied, the moisture removal capacity increases with RH.

\subsubsection{Regeneration at Varying Temperatures}

It is observed in Fig. 5(a) that the addition of hygroscopic substance such as $\mathrm{LiCl}$ and $\mathrm{CaCl}_{2}$ lowers the regeneration capacity of composite desiccants. This is attributed to the chemical bond formed by water molecules with the hydrophilic salt that potentially retards the diffusion of moisture flow during the regenerative process.

It is apparent from Fig. 5(b) that desiccants incorporated with bentonite generally have a greater effect from changing regeneration temperature. As illustrated by the graphs, the regenerative capability of silica gel at $900^{\circ} \mathrm{C}$ marginally improved when compared to 
the one at $700^{\circ} \mathrm{C}$. Comparatively, for other composite desiccants, the improvement of the regenerative capability from $700^{\circ} \mathrm{C}$ to $900^{\circ} \mathrm{C}$ is quite significant.

From the graphs shown in Fig. 5(a) and 5(b), it can be inferred that the higher the regeneration temperature, the higher the moisture released from the desiccants. It is also clear that at low regeneration temperatures spanning $60-650^{\circ} \mathrm{C}$, the difference in the moisture released from the desiccants is not significant.

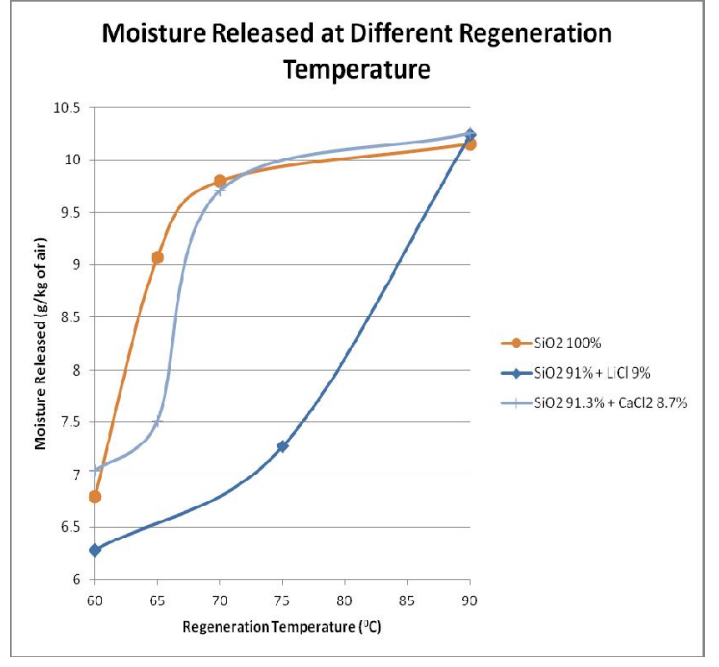

(a)

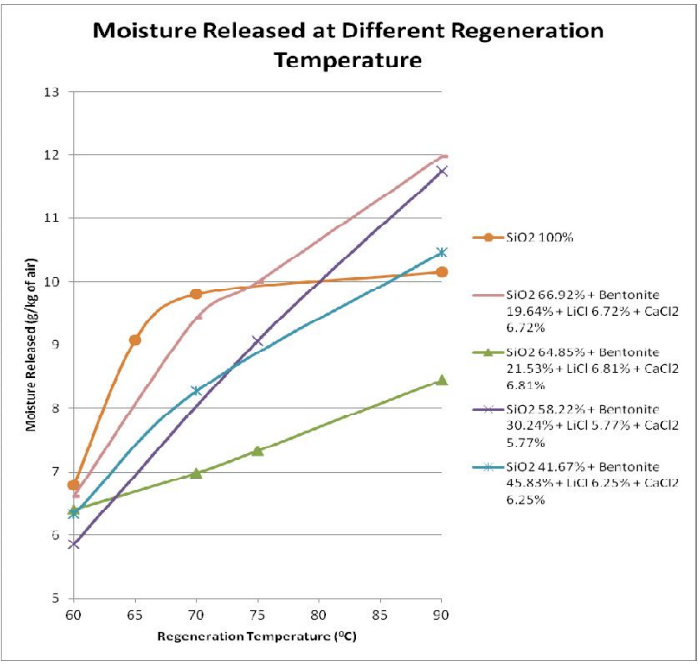

(b)

Fig. 5: (a) Regenerative capability of two-layered composite desiccants as compare to silica gel; and (b) regenerative capability of four-layered composite desiccants as compare to silica gel.

\section{CONCLUDING REMARKS}

In this paper, we have demonstrated that in contrast to silica gel, improved performance of composite desiccants in terms of greater moisture removal capacity as well as better moisture regenerative ability. For the first time, four-layered composite desiccants, comprising of different mass contents of silica gel, lithium chloride, calcium chloride and bentonite, have been developed and studied. In general, each component has contributed in making composite desiccants perform relatively better compared to silica gel - lithium chloride. The best performing moisture adsorbing four-layered desiccant is $\mathrm{SiO}_{2} 64.85 \%+$ bentonite $21.53 \%+\mathrm{LiCl} 6.81 \%+\mathrm{CaCl}_{2} 6.81 \%$ by mass. This composite desiccant was evaluated to have similar moisture removal capacity to a silica gel-lithium chloride combination. Furthermore, its regeneration capacity at a lower temperature of $60^{\circ} \mathrm{C}$ was found to be close to pure silica gel and silica gel-lithium chloride. In The pressure drop across this composite desiccant was determined to be $27 \%$ and $34 \%$ lower than that of pure silica gel and silica gel-lithium chloride, respectively.

\section{ACKNOWLEDGEMENT}

The authors gratefully acknowledges the kind support of Agency for Science, Technology and Research (A*Star) and Ministry of National Development (MND) through their Green Building Joint Grant (no: 112176 0023) funding for this research and the effort of Mr. Vincent Marthawan JongHong in conducting the experiments presented in this work. 


\section{REFERENCES}

[1] American Society of Heating, Refrigerating and Air-Conditioning Engineers, Thermal Environmental Conditions for Human Occupancy, Atlanta, 2004.

[2] Arundel, Sterling E, Bigging J, Sterling T. (1986) Indirect health effects of relative humidity in indoor environment. Environmental Health Perspectives, 65:351-361.

[3] Air-Con System Efficiency Primer: A Summary. (2011). [Online]. Available: http://app.nccs.gov.sg/data/resources/docs/TechPrimers/Aircon\%20Primer.pdf?AspxAutoDe tectCookieSupport=1. [Accessed 23 February 2013].

[4] Daou K, Wang R, Xia Z. (2006) Desiccant cooling air conditioning: a review. Renewable and Sustainable Energy Reviews, 10:55-77.

[5] Katejanekarn T, Kumar S. (2008) Performance of a solar-regenerated liquid desiccant ventilation pre-conditioning system. Energy and Buildings, 40:1252-1267.

[6] Techajunta S, Chirarattananon S, Exell R. (1999) Experiments in solar simulator on solid desiccant regeneration and air dehumidification for air conditioning in a tropical humid climate. Renewable Energy, 17:549-568.

[7] Li X, Li Z, Xia Q and Xi H. (2007) Effects of pore sizes of porous silica gels on desorption activation energy of water vapour. Applied Thermal Engineering, 27:869-876.

[8] Demir H, Mobedi M, Ulku S. (2011) Microcalorimetric investigation of water vapor adsorption on silica gel. J Therm Anal Calorim, 105:375-382.

[9] Chang K, Wang H, Chung T. (2004) Effect of regeneration conditions on the adsorption dehumidification process in packed silica gel beds. Applied Thermal Engineering, 24:735742.

[10] Jia C, Dai Y, Wu J, Wang R. (2007) Use of compound desiccant to develop high performance. International Journal of Refrigeration, 30:345-353.

[11] Ng K, Chua H, Chung C, Loke C, Kashiwagi T, Akisawa A, Saha B. (2001) Experimental investigation of silica gel-water adsorption isotherm characteristics. Applied Thermal Engineering, 21:1632-1642.

[12] Özdinç MC, Yildirim M. (2004) Energy and exergy analyses of an experimental open-cycle desiccant cooling system. Applied Thermal Engineering, 24:919-932.

[13] Proverbio E, Restuccia G, Russo F, Bonaccorsi L, Freni A. (2006) Zeolite coated copper foams for heat pumping applications, Microporous and Mesoporous Materials, 91:7-14.

[14] Aristov Y, Restuccia G, Cacciola G, Parmon V. (2002) A family of new working materials for solid sorption air conditioning systems. Applied Thermal Engineering, 22:191-204.

[15] Smith, DM, Lucky, EA, Natividad, V. (2000) Desiccant composition. USA Patent 6559096.

[16] Zhang X, Sumathy K, Dai Y, Wang R. (2006) Dynamic hygroscopic effect of the composite material used in desiccant rotary wheel. Solar Energy, 80:1058-1061.

[17] Zhang X, Qiu L. (2007) Moisture transport and adsorption on silica gel-calcium chloride composite adsorbents. Energy Conversion and Management, 48:320-326.

[18] Mandegari M, Pahlavanzadeh H. (2009) Introduction of a new definition for effectiveness of desiccant wheels. Energy, 34:797-803.

[19] Jia C. (2011) Study on adsorption mechanism and dehumidification property of composite desiccant. Advanced Materials Research, 150-151:912-916.

[20] Gordeeva L, Grekova A, Krieger T, Aristov. (2009) Adsorption properties of composite materials $(\mathrm{LiCl}+\mathrm{LiBr}) /$ silica. Microporous and Mesoporous Materials, 12:262-267.

[21] Thoruwa T, Johnstone C, Grant A, Smith J. (2000) Novel, low cost $\mathrm{CaCl}_{2}$ based desiccants for solar crop drying applications. Renewable Energy, 19:513-520.

[22] Tretiak C, Ben Abdallah N. (2009) Sorption and desorption characteristics of a packed bed of clay- $\mathrm{CaCl}_{2}$ desiccant particles. Solar Energy, 83:1861-1870. 